\title{
Biofouling of inlet pipes affects water quality in running seawater aquaria and compromises sponge cell proliferation
}

Brittany E Alexander, Benjamin Mueller, Mark JA Vermeij, Harm HG van der Geest, Jasper M de Goeij

Marine organism are often kept, cultured, and experimented on in running seawater aquaria. However, surprisingly little attention is given to the nutrient composition of the water flowing through these systems, which is generally assumed to equal in situ conditions, but may change due to the presence of biofouling organisms. Significantly lower bacterial abundances and higher inorganic nitrogen species (nitrate, nitrite, and ammonium) were measured in aquarium water when biofouling organisms were present within a 7-year old inlet pipe feeding a tropical reef running seawater aquaria system, compared with aquarium water fed by a new, biofouling-free inlet pipe. These water quality changes are indicative of the feeding activity and waste production of the suspension- and filter-feeding communities found in the old pipe, which included sponges, bivalves, barnacles, and ascidians. To illustrate the physiological consequences of these water quality changes on a model organism kept in the aquaria system, we investigated the influence of the presence and absence of the biofouling community on the functioning of the filter-feeding sponge Halisarca caerulea, by determining its choanocyte (filter cell) proliferation rates. We found a $34 \%$ increase in choanocyte proliferation rates following the replacement of the inlet pipe (i.e. removal of the biofouling community). This indicates that the physiological functioning of the sponge was compromised due to suboptimal food conditions within the aquarium resulting from the presence of the biofouling organisms in the inlet pipe. This study has implications for the husbandry and performance of experiments with marine organisms in running seawater aquaria systems. Inlet pipes should be checked regularly, and replaced if necessary, in order to avoid excessive biofouling and to approach in situ water quality. 
1 Biofouling of inlet pipes affects water quality in running seawater aquaria and compromises sponge cell proliferation

3

4

5 Brittany E. Alexander ${ }^{1 \S}$, Benjamin Mueller ${ }^{2}$, Mark J. A. Vermeij ${ }^{2,3}$, Harm G. van der Geest ${ }^{1}$, 6 Jasper M. de Goeij ${ }^{1,2 \S^{*}}$

91 Department of Aquatic Environmental Ecology, Institute for Biodiversity and Ecosystem 10 Dynamics, University of Amsterdam, Post Office Box 94248, 1090 GE Amsterdam, The 11 Netherlands.

$12{ }^{2}$ CARMABI Foundation, Piscaderabaai z/n, Willemstad, Curaçao

$13{ }^{3}$ Department of Aquatic Microbiology, Institute for Biodiversity and Ecosystem Dynamics, 14 University of Amsterdam, Post Office Box 94248, 1090 GE Amsterdam, The Netherlands.

$16 \S$ Contributed equally to the work

17 * Corresponding author: j.m.degoeij@uva.nl 


\section{Abstract}

Marine organism are often kept, cultured, and experimented on in running seawater aquaria. However, surprisingly little attention is given to the nutrient composition of the water flowing through these systems, which is generally assumed to equal in situ conditions, but may change due to the presence of biofouling organisms. Significantly lower bacterial abundances and higher inorganic nitrogen species (nitrate, nitrite, and ammonium) were measured in aquarium water when biofouling organisms were present within a 7-year old inlet pipe feeding a tropical reef running seawater aquaria system, compared with aquarium water fed by a new, biofouling-free inlet pipe. These water quality changes are indicative of the feeding activity and waste production of the suspension- and filter-feeding communities found in the old pipe, which included sponges, bivalves, barnacles, and ascidians. To illustrate the physiological consequences of these water quality changes on a model organism kept in the aquaria system, we investigated the influence of the presence and absence of the biofouling community on the functioning of the filter-feeding sponge Halisarca caerulea, by determining its choanocyte (filter cell) proliferation rates. We found a $34 \%$ increase in choanocyte proliferation rates following the replacement of the inlet pipe (i.e. removal of the biofouling community). This indicates that the physiological functioning of the sponge was compromised due to suboptimal food conditions within the aquarium resulting from the presence of the biofouling organisms in the inlet pipe. This study has implications for the husbandry and performance of experiments with marine organisms in running seawater aquaria systems. Inlet pipes should be checked regularly, and replaced if necessary, in order to avoid excessive biofouling and to approach in situ water quality. 


\section{Introduction}

Running seawater aquaria are frequently used to study the physiology of marine organisms under controlled, ex situ condition (e.g., Wilkerson, Muscatine, 1984; Enríquez, Méndez \& Prieto, 2005; Anthony et al., 2008; Duckworth, Peterson, 2013). In the experimental design and set-up of such studies, ambient physical abiotic factors, such as light, temperature, and water flow are given the most attention since these are well known to deviate from in situ conditions. However, surprisingly little attention is given to biotic and chemical abiotic factors in running seawater aquaria systems, which are usually only monitored in specific feeding or nutrient-enrichment experiments (e.g., Tacon et al., 2002; Jiménez, Ribes, 2007; Bracken, 2004). It is generally assumed that the chemical and biological composition of the seawater flowing through aquaria matches in situ ambient water. The extent to which changes in water quality occur within running seawater aquaria and the potential effect of this on the physiology of experimental marine organisms remains largely unknown. proliferative cells measured in the sponge Halisarca caerulea (Porifera: Demospongiae) during two distinct fieldwork periods of several months, using the same running seawater aquaria system and identical methodology. In the first series of experiments, the proliferation rate of $H$. caerulea filter cells (choanocytes), i.e. the percentage of proliferative choanocytes after 6 hours, was estimated to be $46.6 \pm 2.6 \%$ (mean $\pm 95 \%$-CI) under steady-state (negligible growth) conditions (De Goeij et al., 2009). During the second series of experiments, which were performed five to seven years later, we measured a significantly lower choanocyte proliferation rate of $17.6 \pm 3.3 \%$ for the same species (Alexander et al., 2014; Alexander et al., 2015). We 
64 discussed and hypothesized the possible cause of this altered cell proliferation to be a suboptimal

65 food supply to the aquaria during the latter fieldwork period (Alexander et al., 2014; Alexander

66 et al., 2015). Preliminary tests also showed that during that second fieldwork period the bacterial

67 abundances in the aquaria water were approximately three times lower $\left(3.0 \times 10^{5}\right.$ per $\left.\mathrm{mL}\right)$ than in

68

69 water samples taken at the reef entrance of the inlet pipe $\left(8.8 \times 10^{5}\right.$ per $\left.\mathrm{mL}\right)$. Bacterial numbers are a good proxy indicating the food availability to sponges. The natural diet of these filterfeeding organisms mainly consists of bacterio- and phyto-plankton (e.g., Pile et al., 1997; Ribes, Coma \& Gili, 1999), and dissolved organic matter (Yahel et al., 2003; De Goeij et al., 2008; Mueller et al., 2014). The average bacterial retention efficiency is high, ranging between $68-95 \%$ for a wide range of tropical- (Mueller et al., 2014), temperate- (Pile, Patterson \& Witman, 1996), and cold-water (Yahel et al., 2007) sponge species. The low bacterial abundances observed in our running seawater aquaria could therefore indeed point toward suboptimal nutritional conditions and may explain the compromised physiology of our experimental organisms.

Biofouling is a common problem reported in power plants and desalinization factories that use running seawater (e.g., Azis, Al-Tisan \& Sasikumar, 2001; Railkin, 2003), and can affect water quality and hydrodynamic patterns (Flemming, Geesey, 1991). The low bacterial abundances in our running seawater aquaria may, therefore, have been caused by the activity of biofouling communities, such as suspension- or filter-feeding organisms, established on the inside walls of inlet pipes. The initial cell proliferation study (De Goeij et al., 2009) was carried out when the aquaria inlet pipe had been in place for only a few months, whereas the inlet pipe in the latter study (Alexander et al., 2014) had been in place for seven years, allowing much more time for the establishment of biofouling communities. In addition, water flowing through running seawater aquaria may experience an increase in inorganic nutrients due to excreted waste 
87 products from these biofouling communities (e.g., Smaal, Prins, 1993; Southwell et al., 2008).

88 However, limited data is currently available on the effects of biofouling on the water quality of running seawater aquaria used to conduct physiological and ecological experiments on marine

90 organisms.

92 To gain a better insight into the effect of biofouling on water quality and the outcome of experiments held in running seawater aquaria we asked the following research questions: Is water quality within our running seawater aquaria system affected by biofouling communities? If so, do bacterial abundances increase and nutrient concentrations decrease after the removal of such communities, i.e. by replacing the old inlet pipe? Does the presence of biofouling communities significantly hamper the physiology of experimental organisms kept in open seawater aquaria? In order to answer these questions, the bacterial abundances and inorganic nutrient concentrations (nitrate, nitrite, ammonium, and phosphate) were assessed in the reef water flowing along the length of the inlet pipe and in the flow-through aquarium fed by the inlet pipe. Subsequently, the presence and distribution of biofouling communities inside the 7-year old pipe was investigated. After replacing the old inlet pipe, the aforementioned water quality assessments were repeated, and the choanocyte proliferation rates for our model organism $H$. caerulea were determined before and after the installation of the new inlet pipe. 
107

108

109

110

111

112

113

114

115

116

117

118

119

120

121

122

123

124

125

126

127

128

129

\section{Materials and Methods}

Fieldwork was performed under the research permit (\#2012/48584) issued by the Curaçaoan Ministry of Health, Environment and Nature (GMN) to the CARMABI foundation.

\section{Running seawater aquaria system}

The running seawater aquaria system is located on the Southern Caribbean island of Curaçao at the CARMABI research station $\left(12^{\circ} 12^{\prime} \mathrm{N}, 68^{\circ} 56^{\prime} \mathrm{W}\right)$. The land-based facility consists of 18 glass flow-through aquaria ranging in volume from 50-160 L. Seawater is pumped (Hayward Super Pump SP0150Z1CM; capacity $400 \mathrm{~L} \mathrm{~min}^{-1}$ ) from $10 \mathrm{~m}$ water depth at the reef slope through a 100-m long polypropylene pipe (inner $\varnothing 5 \mathrm{~cm}$ ). The first $60 \mathrm{~m}$ of the pipe lies underwater, whereas the last $40 \mathrm{~m}$, including the pump, is located above-water, partially underground. Water flow is regulated separately for each flow-through aquarium. The last time the old inlet pipe of the running seawater aquaria system had been replaced was in 2006 . The new inlet pipe (only the first $60 \mathrm{~m}$ of the underwater section) was replaced on April 6 ${ }^{\text {th }}, 2013$.

\section{Sponge collection}

All specimens of the encrusting sponge $H$. caerulea were collected from the fringing coral reefs on the leeward coast of Curaçao (Southern Caribbean, $12^{\circ} 12^{\prime} \mathrm{N}, 68^{\circ} 56^{\prime} \mathrm{W}$ ) at $15-30 \mathrm{~m}$ water depths by SCUBA between February and March 2013, 1-2 months before the replacement of the old pipe. Pieces of sponge were chiseled from the reef framework and the attached substrate was cleared of other organisms. All sponges were trimmed to a size of approximately $25 \mathrm{~cm}^{2}$ and subsequently kept in 100-L running seawater aquaria, with a flow rate of $3 \mathrm{~L} \mathrm{~min}^{-1}$. Aquarium 
130 water was at ambient seawater temperature $\left(26-27^{\circ} \mathrm{C}\right)$ and kept under natural light cycles (the 131 semi-enclosed aquarium building receives natural daylight). Semi-transparent black plastic

132 sheets were used to imitate in situ cryptic (i.e. the collected sponges inhabited coral cavity walls)

133 light conditions that sponges experienced (photosynthetically active radiation (PAR) level 5-15

$134 \mu \mathrm{mol}$ photons $\mathrm{m}^{-2} \mathrm{~s}^{-1}$ during daylight hours). Prior to cell proliferation experiments, sponges

135 acclimatized to aquarium conditions for a minimum of 1 week before and after the old pipe was

136 replaced by the new pipe to insure they fully recovered from the collection and transportation to

137 the aquaria (De Goeij et al. 2009; Alexander et al. 2014, 2015).

138

\section{Water sample collection}

140 Water samples were taken inside the old pipe on March 22, 2013 and inside the new pipe on

141 April 9, 2013, $3 \mathrm{~d}$ after its installation. To sample water from the center of the inlet pipe, $\varnothing 1.5$

$142 \mathrm{~mm}$ holes were drilled underwater using a hand drill through which samples were collected using

$14320 \mathrm{~mL}$ syringes with needle. The holes were sealed afterwards with marine PC-11 two-

144 component epoxy (Protective Coating Company, USA). Triplicate $20 \mathrm{~mL}$ water samples were

145 taken to determine bacterial abundances and inorganic nutrient concentrations along the length of

146 the old and new inlet pipes at 0 (a few cm inside the inlet pipe), 3, 6, 12, 24, and $60 \mathrm{~m}$ from the 147 inlet pipe entrance (Fig. 1 and Fig. S1) as well as in one of the flow-through aquaria at $100 \mathrm{~m}$ 148 from the entrance of the inlet pipe.

150 Analysis of bacterial abundance

151 Ten $\mathrm{mL}$ of the water sample was fixed immediately with $0.57 \mathrm{~mL} 35 \%$ formaldehyde solution 152 (final concentration $\sim 2 \%$ ) for $1 \mathrm{~h}$ at $4^{\circ} \mathrm{C}$ in the dark. Fixed samples were then filtered on $0.2 \mu \mathrm{m}$ 
153 polycarbonate filters (25 mm, Nuclepore Track-Etch, Whatman, UK) with $0.45 \mu \mathrm{m}$ cellulose 154 nitrate support filters (25 mm, Sartorius Stedim Biotech GmbH, Germany). The polycarbonate 155 filters were air-dried and stored at $-20^{\circ} \mathrm{C}$ until further processing. Filters were mounted on 156 microscope slides in DAPI-mix (final concentration $1 \mu \mathrm{g} \mathrm{L}^{-1}$ ) and bacteria were counted using an 157 epifluorescence microscope $(\times 1250)$. At least ten fields (each $\left.0.0025 \mathrm{~mm}^{2}\right)$ of a counting grid 158 were counted per slide, or up to a minimum of 200 bacteria, when ten fields were not sufficient.

160 Analysis of inorganic nutrients

161 Five $\mathrm{mL}$ of the water sample was filtered using a $0.2 \mu \mathrm{m}$ syringe filter (25 mm Puradisc, 162 Whatman, UK) and stored at $-20^{\circ} \mathrm{C}$ in $6 \mathrm{~mL}$ vials (Pico Prias, Perkin Elmer USA) until further 163 processing. The concentrations of dissolved inorganic nutrients (nitrate $\left[\mathrm{NO}_{3}^{-}\right]$, nitrite $\left[\mathrm{NO}_{2}^{-}\right]$, 164 ammonium $\left[\mathrm{NH}_{4}^{-}\right]$, ortho-phosphate $\left[\mathrm{PO}_{4}{ }^{3-}\right]$ ) were measured colorimetrically on a Skalar 165 segmented flow autoanalyzer according to the manufacturer's directions.

166

\section{BrdU-labeling and sponge tissue sampling}

168 Sponges ( $n=3$ before and $n=3$ after installation of the new pipe; all different individuals) were enclosed in incubation chambers (3 L) with magnetic stirring devices (De Goeij et al., 2009;

170 Alexander et al., 2014; Alexander et al., 2015), which were kept in the aquaria during the 171 experiments to maintain ambient seawater temperature. In order to measure cell proliferation, 5172 bromo-2'-deoxyuridine (BrdU, Sigma) was added to incubation chambers containing the 173 sponges. Sponges were incubated in seawater containing $50 \mu \mathrm{mol} \mathrm{L}-1$ BrdU for $6 \mathrm{~h}$ (continuous 174 labeling) in order to estimate choanocyte proliferation rates (Nowakowski, Lewin \& Miller, 175 1989; De Goeij et al., 2009; Alexander et al., 2014). Immediately after the incubations, one 
176 tissue sample $\left(\sim 0.5 \mathrm{~cm}^{2}\right)$ was taken from each sponge and fixed in $4 \%$ paraformaldehyde in

177 phosphate-buffered saline (PFA/PBS; $4 \mathrm{~h}$ at $4^{\circ} \mathrm{C}$ ), rinsed in PBS, dehydrated through a graded

178 series of ethanol and stored in $70 \%$ ethanol at $4^{\circ} \mathrm{C}$ until further processing.

179

180

\section{Sponge cell proliferation}

181 Histological sections ( $3 \mu \mathrm{m})$ of BMM-embedded sponge tissue were cut on a pyramitome (LKB 182 11800, UK) using glass knives and collected on glass slides (StarFrost, Knittelglass, Germany).

183 BrdU immunohistochemistry was performed according to Alexander and colleagues (2014, 184 2015) using a mouse anti-BrdU monoclonal antibody (Nordic-MUbio MUB0200S, The 185 Netherlands), which was detected with an avidin-biotin enzyme complex (Vectastain Elite ABC 186 Kit, Vector laboratories). BrdU-positive cells were visualized with DAB (DAKO, Denmark) on 187 haematoxylin-counterstained sections, and mounted in Entellan (Merck, USA). BrdU-labeled 188 mouse intestinal tissue was used as a positive control and immunohistochemistry without 189 primary antibody (on both mouse and sponge tissue) served as a negative control, as previously 190 described (Alexander et al., 2014). All slides were examined under a light microscope (Olympus 191 BH-2) and photographs were taken using an Olympus DP70 camera. From each tissue sample, 192 three areas of the sponge were sectioned, each approximately $100 \mu \mathrm{m}$ apart. At least 250 193 choanocytes were counted from each section making a total of at least 750 (three sections x 250 194 cells) cells counted per sponge.

196 Analysis of biofouling in the old inlet pipe

197 After water samples were taken from the old pipe and tissue samples were taken from the 198 sponges in the flow-through aquarium, the $60 \mathrm{~m}$ underwater section of the pipe was removed and 
199 cut into 1-m pieces over its entire length. Each 1-m piece was then cut in half along its length 200 and photographed to assess the presence of biofouling communities (see Fig. 1 for an overview 201 and Fig. S1 for close-up photographs of the biofouling communities in the first $12 \mathrm{~m}$ from the 202 inlet pipe entrance).

203

204 Statistical analysis

205 The differences in bacterial abundance and inorganic nutrients between the old and new pipe and 206 along the length of both pipes were tested using exponential (bacteria) and linear (nutrients) 207 models. Differences in bacterial abundances and dissolved inorganic nutrients were also tested in 208 the water flowing through aquaria fed by the old and new pipe, using linear models. 209 Additionally, differences in choanocyte proliferation rates between sponges kept in flow-through 210 aquaria fed by the old and new pipe were investigated with a linear model. The significance

211 threshold was set at 0.05. All calculations were carried out in R (see S2 for complete dataset 212 (bacterial abundance and inorganic nutrients) and S3 for R-scripts). 


\section{Results}

215

\section{Water quality}

217 Bacterial abundances in water at the reef entrance of the old inlet pipe $\left(7.3 \pm 0.5 \times 10^{5} \mathrm{~mL}^{-1}\right.$;

218 mean $\pm \mathrm{SD})$ were 3.9 fold lower than in the flow-through aquarium $\left(1.9 \pm 0.1 \times 10^{5} \mathrm{~mL}^{-1}\right)($ Fig.

219 2) of the running seawater system. Bacterial abundance decreased with increasing distance from

220 the reef entrance of the old inlet pipe (exponential model, $p=0.009$, Fig. 2) and the largest drop

221 in bacterial abundance occurred in the first $12 \mathrm{~m}$ of the pipe. Nitrate and nitrite concentrations

222 increased significantly with increasing distance from the entrance of the old inlet pipe (linear

223 models, $p=0.008$ [nitrate and nitrite], Fig. 3A, B). The concentration of ammonium increased

224 from the entrance of the old inlet pipe to the flow-through aquaria, but did not significantly

225 increase along the length of the old pipe (linear model, $p=0.5$, Fig. 3C), and no significant

226 difference was observed in the concentration of phosphate along the length of the old pipe (linear

227 model, $p=0.07$, Fig. 3D).

228 The installation of the new pipe caused a significant change in all water quality

parameters ( $p$ values $<0.05$, Fig. 2 and 3A-C), compared to the old pipe, except the

230 concentration of phosphate, which remained similar (linear model, $p=0.77$, Fig. 3D). There was

231 no significant difference between the reef water samples (taken at $0 \mathrm{~m}$ from the pipe entrance)

232 before (March 22, 2013) and after the pipe change (April 9, 2013) for any of the water quality

233 parameters (linear model, $p=0.07$ [bacteria], $p=0.12$ [nitrite, ammonium, and phosphate], $p=$

2340.48 [nitrate]). Bacterial abundance was significantly higher along the length of the new pipe 235 compared to the old (exponential model, $p=0.03$ ) and no longer changed along the length of the

236 new pipe (exponential model, $p=0.80$ ). However, bacterial abundance in the flow-through 
237 aquaria supplied by the new inlet pipe was lower $\left(5.9 \pm 0.2 \times 10^{5} \mathrm{~mL}^{-1}\right.$, Fig. $\left.2 \mathrm{~A}\right)$ compared to the

238 abundance at the reef entrance of the new inlet pipe $\left(7.0 \pm 0.1 \times 10^{5} \mathrm{~mL}^{-1}\right)$. Still, bacterial

239 abundance in the flow-through aquarium fed by the new pipe was 3.1 times higher compared to

240 flow-through aquarium fed by the old pipe $\left(1.9 \pm 0.1 \times 10^{5} \mathrm{~mL}^{-1}\right)$. Dissolved inorganic nitrogen

241 (nitrate, nitrite, and ammonium) concentrations were lower in the new pipe compared to the old

242 pipe (linear models, $p=0.01$ [nitrite], $p=0.01$ [nitrate], $p<0.001$ [ammonium]) and did not

243 change along the length of the new pipe (linear models, $p=0.81$ [nitrite], $p=0.81$ [nitrate], $p=$

2440.85 [ammonium]). However, inorganic nitrogen concentrations were higher in the flow-through 245 aquarium compared to the reef entrance of the new inlet pipe (Fig. 3A-C). Replacing the old 246 pipe, i.e. removing the biofouling community, corresponded to a $42 \%$ reduction in both nitrate 247 and nitrite and a $77 \%$ reduction in ammonium concentrations in the flow-through aquarium 248 (Table 1).

\section{Biofouling}

The first $12 \mathrm{~m}$ of the old inlet pipe showed extensive colonization by biofouling communities (Fig. 1 and Fig. S1), which formed a cm-thick layer of living biomass decreasing its opening from $\varnothing 5 \mathrm{~cm}$ to approximately $\varnothing 3 \mathrm{~cm}$. The abundance of biofouling organisms decreased inwards throughout the pipe and they were absent after $12 \mathrm{~m}$ from the reef entrance of the pipe out, the majority were identified as suspension- and filter-feeding organisms, including sponges, bivalves, barnacles, and ascidians.

\section{Sponge cell proliferation}


260 Sponges kept in the aquaria in the presence of biofouling communities before the inlet pipe was

261 replaced had a significantly lower choanocyte proliferation rate $(15.1 \pm 1.9 \%$ in $6 \mathrm{~h})$ than

262 sponges after the installation of the new inlet pipe $(20.2 \pm 3.8 \%$ in $6 \mathrm{~h}$, linear model, $p<0.05$,

263 Table 1). The replacement of the pipe thus coincided with a $34 \%$ increase in the choanocyte

264 proliferation rates of sponges kept in the aquaria over a 7-d period (Table 1). 


\section{Discussion}

266

267 Here we present a study showing that biofouling of an inlet pipe feeding running seawater

268

269

270

271

272

273

274

275

276

277

278

279

280

281

282

283

284

285

286

287 aquaria coincided with a decrease in bacterial abundance and an increase in dissolved inorganic nitrogen (ammonium, nitrate and nitrite) within the aquarium water. These alterations are logical consequences of the biological activity of suspension- and filter-feeding biofoulers, which included sponges, bivalves, barnacles, and ascidians (e.g., Reiswig, 1975; Smaal, Prins, 1993; Williamson, Rees, 1994; Ribes et al., 2005; Petersen, 2007; Southwell et al., 2008). Bacteria are an important food source for suspension- and filter-feeders, and the largest decrease in their abundance occurred within the first 12 meters of the pipe where all biofouling organisms were found. Consequently, this created unfavorable conditions for the filter-feeding sponges kept in the running seawater aquaria system due to diminished food supplies (i.e. bacteria) and the buildup of waste products (inorganic nutrients). The new inlet pipe was free from biofouling organisms, which subsequently caused both bacterial abundance and concentrations of nitrate, nitrite, and ammonium to approach ambient reef water conditions.

Interestingly, after replacing the pipe a slight decrease in bacterial abundance and an increase in inorganic nitrogen species remained between water sampled at the entrance of the inlet pipe and the flow-through aquarium water. This could either be caused by the prevalent presence of biofouling organisms in the underground pipe section that was not replaced, or the presence of the pump in that section. The first suggestion is unlikely, since we did not find any biofouling organisms beyond the first 12 meters of the pipe. Microbial biofilms may have colonized this area (Railkin, 2003), but these would not have caused bacterial abundances to decrease. The 
288 more likely explanation is that the pump may have caused some destruction of bacterioplankton

289 by its impellor force (Luckett et al., 1996). Within the aquarist community, high pressure and

290 cavitation caused by impellor pumps are commonly known to damage a significant proportion of

291 the resident planktonic community (e.g., Wijgerde 2012 and discussed on the reef aquarist forum

292 Reef Central 2008), and could have subsequently led to a lower bacterial abundance and an

293 increase in inorganic nutrients in the flow-through aquarium. Bacterial abundance in the

294 aquarium fed by the new inlet pipe $\left(5.9 \pm 0.2 \times 10^{5} \mathrm{~mL}^{-1}\right)$ where nevertheless still in the range of

295 ambient in situ bacterial abundances measured for Curaçaoan reef waters $\left(5-10 \times 10^{5} \mathrm{~mL}^{-1}\right)($ De

296 Goeij, van Duyl, 2007).

297 We documented a clear 34\% increase in the proliferation rate of choanocytes in $H$.

298 caerulea following the replacement of the inlet pipe. The cause of this increase cannot be

299 unequivocally linked to changes in our water quality proxies. However, to the best of our

300 knowledge, the only parameter that was changed in this case study was the inlet pipe. It is well

301 established that cell proliferation is an energetically costly process, which requires a constant

302 supply of energy and nutrients (reviewed by Vander Heiden, Cantley \& Thompson, 2009) and

303 can become significantly reduced, or even halted, in response to environmental stress (Johnson,

304 Walker, 1999; Jonas, 2014). Nutrition is a pivotal determinant in the regulation of cell

305 proliferation for the maintenance of tissue homeostasis in metazoans. Starvation causes a

306 reduction in cell proliferation (Chaudhary et al., 2000; Park, Takeda, 2008), which is reversed

307 following re-feeding (Aldewachi et al., 1975). The direct relationship between nutrient

308 concentration and cell proliferation in sponges must be investigated further, but we have found

309 preliminary evidence that cell proliferation increases with increasing food supply, using bacterial

310 abundance as proxy for food concentrations. Other energetically costly processes, such as 
311 reproduction or regeneration, may also cause changes in sponge cell proliferation rates. For the

312 closely related sponge Halisarca dujardini it was found that up to $69.5 \%$ of their body volume

313 could consist of reproductive elements (Ereskovsky 2000) during their reproductive cycle

314 (presumably causing less energy spent in choanocyte turnover) and cell proliferation

315 significantly decreases during regeneration after wound infliction (Alexander et al. 2015).

316 Unfortunately, to the best of our knowledge, there is no available literature on the reproductive

317 cycle of Halisarca caerulea. We randomly found reproductive elements in histological sections,

318 both oocytes and spermatic cysts, throughout both multi-months fieldwork periods, but it

319 appeared they did not alter the choanocyte proliferation rates during experiments. During

320 regeneration, choanocyte proliferation rates of sponge specimens residing in the aquaria fed by

321 the old inlet pipe were reduced $(7.0 \pm 2.5 \%$ in 6 hours $)$ within the first hours after wound

322 infliction. However, after 6 days proliferation rates did not differ significantly anymore from

323 those in steady-state tissue (i.e. the 'normal' physiological state of these sponges showing limited

324 growth and a high turnover of choanocytes) $(12.8 \pm 1.0 \%$ in 6 hours) (Alexander et al. 2015).

Despite the 34\%-increase found in this study, the proliferation rate of choanocytes for $H$.

326 caerulea after replacement of the inlet pipe $(20.2 \pm 3.8 \%$ in 6 hours $)$ was still substantially lower

327 than found during an earlier study by De Goeij and colleagues (2009) (46 $\pm 2.6 \%$ in 6 hours). We

328 measured cell proliferation only seven days after the old pipe was replaced and have,

329 unfortunately, not been able to sample sponges at later time points. We hypothesize that after

330 prolonged stress, such as malnutrition, sponges are likely to have required a longer

331 acclimatization period to reach a higher rate of choanocyte proliferation. 


\section{Conclusions}

335 In conclusion, this study has implications for the husbandry of marine organisms in running 336 seawater aquaria systems. We have found that biofouling communities residing in the inlet pipes 337 that feed running seawater aquaria significantly alter the water quality between in situ ambient 338 and ex situ aquarium conditions. Our results suggest that this unwillingly compromised the 339 physiology of organisms kept in these aquaria, which can easily lead to the wrong conclusions

340 being drawn from experimental work. This also applies to organisms that may in fact benefit 341 from low bacterial abundances and high inorganic nutrient concentrations, such as algae and 342 corals. Inlet pipes provide an optimal habitat for biofouling organisms due to a lack of predation, 343 reduced competition from a lack of light, and a constant supply of food (Polman, Verhaart \&

344 Bruijs, 2013). They should be checked regularly — and replaced if necessary — in order to avoid 345 excessive biofouling and to ensure that water quality in the aquaria is as close to in situ 346 conditions as possible. 


\section{Acknowledgements}

350 We thank Dick van Oevelen and Peter van Breughel from the Royal Netherlands Institute for Sea

351 Research, Yerseke, for their help with inorganic nutrient analysis. We thank Wim Admiraal and

352 Ronald Osinga for commenting on drafts of the manuscript. 


\section{References}

355

356 Aldewachi HS, Wright NA, Appleton DR, Watson AJ. 1975. The effect of starvation and

357 refeeding on cell population kinetics in the rat small bowel mucosa. Journal of Anatomy, $358 \quad 119: 105-121$.

359

360

361

362

363

364

365

366

367

368

369

370

371

372

373

374

375

Alexander BE, Achlatis M, Osinga R, van der Geest HG, Cleutjens JPM, Schutte B, de Goeij JM. 2015. Cell kinetics during regeneration in the sponge Halisarca caerulea: how local is the response to tissue damage? PeerJ, 3:e820.

Alexander BE, Liebrand K, Osinga R, van der Geest HG, Admiraal W, Cleutjens JPM, Schutte B, Verheyen F, Ribes M, van Loon E, de Goeij JM. 2014. Cell turnover and detritus production in marine sponges from tropical and temperate benthic ecosystems. Plos One, 9:e109486.

Anthony KR, Kline DI, Diaz-Pulido G, Dove S, Hoegh-Guldberg O. 2008. Ocean acidification causes bleaching and productivity loss in coral reef builders. Proceedings of the National Academy of Sciences of the United States of America, 105:17442-17446.

Azis PA, Al-Tisan I, Sasikumar N. 2001. Biofouling potential and environmental factors of seawater at a desalination plant intake. Desalination, 135:69-82.

Bracken MES. 2004. Invertebrate-mediated nutrient loading increases growth of an intertidal macroalga. Journal of Phycology, 40:1032-1041.

Chaudhary M, Mandir N, FitzGerald AJ, Howard JK, Lord GM, Ghatei MA, Bloom SR, Goodlad RA. 2000. Starvation, leptin and epithelial cell proliferation in the gastrointestinal tract of the mouse. Digestion, 61:223-229. 
376

377

378

379

380

381

382

De Goeij JM, de Kluijver A, van Duyl FC, Vacelet J, Wijffels RH, de Goeij AFPM, Cleutjens JPM, Schutte B. 2009. Cell kinetics of the marine sponge Halisarca caerulea reveal rapid cell turnover and shedding. Journal of Experimental Biology, 212:3892-3900.

De Goeij JM, van den Berg H, van Oostveen MM, Epping EHG, Van Duyl FC. 2008. Major bulk dissolved organic carbon (DOC) removal by encrusting coral reef cavity sponges. Marine Ecology-Progress Series, 357:139-151.

De Goeij JM, van Duyl FC. 2007. Coral cavities are sinks of dissolved organic carbon (DOC). Limnology and Oceanography, 52:2608-2617.

Duckworth AR, Peterson BJ. 2013. Effects of seawater temperature and $\mathrm{pH}$ on the boring rates of the sponge Cliona celata in scallop shells. Marine Biology, 160:27-35.

Ereskovsky AV. 2000. Reproduction cycles and strategies of the cold-water sponges Halisarca dujardini (Demospongiae, Halisarcida), Myxilla incrustans and Iophon piceus (Demospongiae, Poecilosclerida) from the White Sea. The Biological Bulletin, 198:77-87. Enríquez S, Méndez ER, Prieto RI. 2005. Multiple scattering on coral skeletons enhances light absorption by symbiotic algae. Limnology and Oceanography, 50:1025-1032.

Flemming HC, Geesey GG, eds. 1991. Biofouling and Biocorrosion in Industrial Water Systems: Proceedings of the International Workshop on Industrial Biofouling and Biocorrosion, Stuttgart, September, 13-14, 1990: Springer-Verlag.

Jiménez E, Ribes M. 2007. Sponges as a source of dissolved inorganic nitrogen: nitrification mediated by temperate sponges. Limnology and Oceanography, 52:948-958.

Johnson D, Walker C. 1999. Cyclins and cell cycle checkpoints. Annual Review of Pharmacology and Toxicology, 39:295-312. 
398 Jonas K. 2014. To divide or not to divide: control of the bacterial cell cycle by environmental 399 cues. Current opinion in microbiology, 18:54-60.

400 Luckett C, Adey WH, Morrissey J, Spoon DM. 1996. Coral reef mesocosms and microcosms401 successes, problems, and the future of laboratory models. Ecological Engineering, 6:57-72.

402 Mueller B, de Goeij JM, Vermeij MJA, Mulders Y, van der Ent E, Ribes M, van Duyl FC. 2014. 403 Natural diet of coral-excavating sponges consists mainly of dissolved organic carbon $404 \quad$ (DOC). Plos One, 9:e90152.

405

406

407

408

409

410

411

412

413

414

415

416

417

418

419

420

Nowakowski R, Lewin S, Miller M. 1989. Bromodeoxyuridine immunohistochemical determination of the lengths of the cell cycle and the DNA-synthetic phase for an anatomically defined population. Journal of Neurocytology, 18:311-318.

Park MS, Takeda M. 2008. Starvation suppresses cell proliferation that rebounds after refeeding in the midgut of the American cockroach, Periplaneta americana. Journal of Insect Physiology, 54:386-392.

Petersen JK. 2007. Ascidian suspension feeding. Journal of Experimental Marine Biology and Ecology, 342:127-137.

Pile A, Patterson M, Witman J. 1996. In situ grazing on plankton $<10 \mu \mathrm{m}$ by the boreal sponge Mycale lingua. Marine Ecology-Progress Series, 141:95-102.

Pile A, Patterson M, Savarese M, Chernykh V, Fialkov V. 1997. Trophic effects of sponge feeding within Lake Baikal's littoral zone. 2. Sponge abundance, diet, feeding efficiency, and carbon flux. Limnology and Oceanography, 42:178-184.

Polman H, Verhaart F, Bruijs M. 2013. Impact of biofouling in intake pipes on the hydraulics and efficiency of pumping capacity. Desalination and Water Treatment, 51:997-1003.

Railkin AI, ed. 2003. Marine biofouling: colonization processes and defenses: CRC press. 
421 Reef Central. 2008. http://www.reefcentral.com/forums/showthread.php?t=1315554

422 Reiswig HM. 1975. Bacteria as food for temperate-water marine sponges. Canadian Journal of

423

424

425

426

427

428

429

430

431

432

433

434

435

436

437

438

439

440

441 Zoology, 53:582-589.

Ribes M, Coma R, Gili JM. 1999. Natural diet and grazing rate of the temperate sponge Dysidea avara (Demospongiae, Dendroceratida) throughout an annual cycle, 176:179-190.

Ribes M, Coma R, Atkinson MJ, Kinzie RA. 2005. Sponges and ascidians control removal of particulate organic nitrogen from coral reef water. Limnology and Oceanography, 50:14801489.

Smaal A, Prins T. 1993. The uptake of organic matter and the release of inorganic nutrients by bivalve suspension feeder beds. In: Dame RF, ed. Bivalve Filter Feeders. Berlin Heidelberg: Springer, 271-298.

Southwell MW, Weisz JB, Martens CS, Lindquist N. 2008. In situ fluxes of dissolved inorganic nitrogen from the sponge community on Conch Reef, Key Largo, Florida. Limnology and Oceanography, 53:986-996.

Tacon AGJ, Cody JJ, Conquest LD, Divakaran S, Forster IP, Decamp OE. 2002. Effect of culture system on the nutrition and growth performance of Pacific white shrimp Litopenaeus vannamei (Boone) fed different diets. Aquaculture Nutrition, 8:121-137.

Vander Heiden MG, Cantley LC, Thompson CB. 2009. Understanding the Warburg effect: the metabolic requirements of cell proliferation. Science, 324:1029-1033.

Wijgerde T. 2012. Improved husbandry of marine invertebrates using an innovative filtration technology - Part 1: DyMiCo. Advanced Aquarist, 11. 
442 Wilkerson FP, Muscatine L. 1984. Uptake and assimilation of dissolved inorganic nitrogen by a 443 symbiotic sea anemone. Proceedings of the Royal Society of London B: Biological Sciences, 221:71-86.

445

Williamson J, Rees T. 1994. Nutritional interaction in an alga-barnacle association. Oecologia, 446 99:16-20.

Yahel G, Sharp J, Marie D, Hase C, Genin A. 2003. In situ feeding and element removal in the symbiont-bearing sponge Theonella swinhoei: Bulk DOC is the major source for carbon. Limnology and Oceanography, 48:141-149.

Yahel G, Whitney F, Reiswig HM, Eerkes-Medrano DI, Leys SP. 2007. In situ feeding and metabolism of glass sponges (Hexactinellida, Porifera) studied in a deep temperate fjord with a remotely operated submersible. Limnology and Oceanography, 52:428-440. 


\section{Figures}

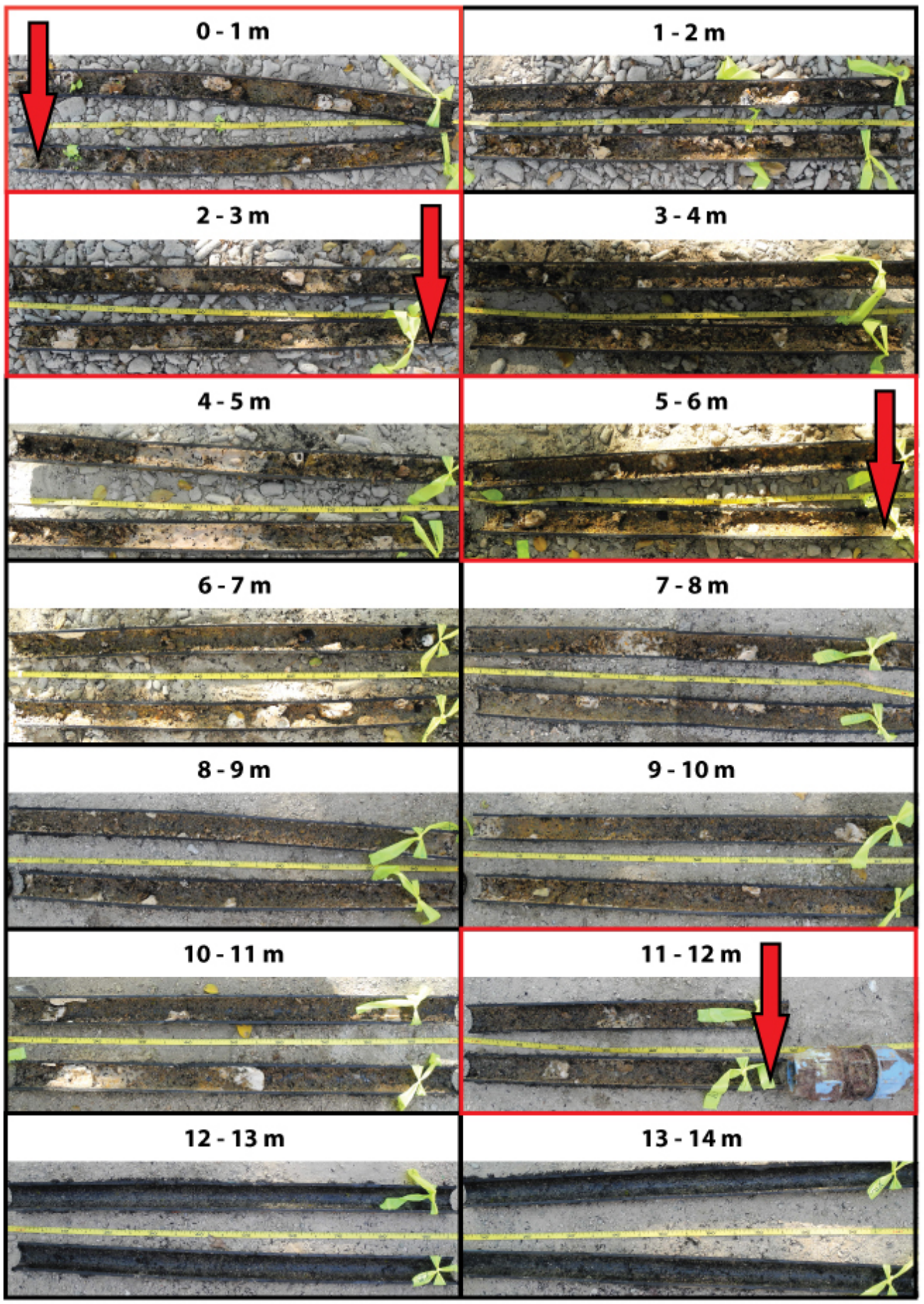

Figure 1. Biofouling communities within the old inlet pipe. The first $14 \mathrm{~m}$ from the entrance

457 of the inlet pipe are shown. No biofouling communities were found after the initial $12 \mathrm{~m}$. Water 
458 samples inside the pipe were taken from areas of the pipe outlined in red and marked by the red

459 arrows $(0,3,6$, and $12 \mathrm{~m})$.

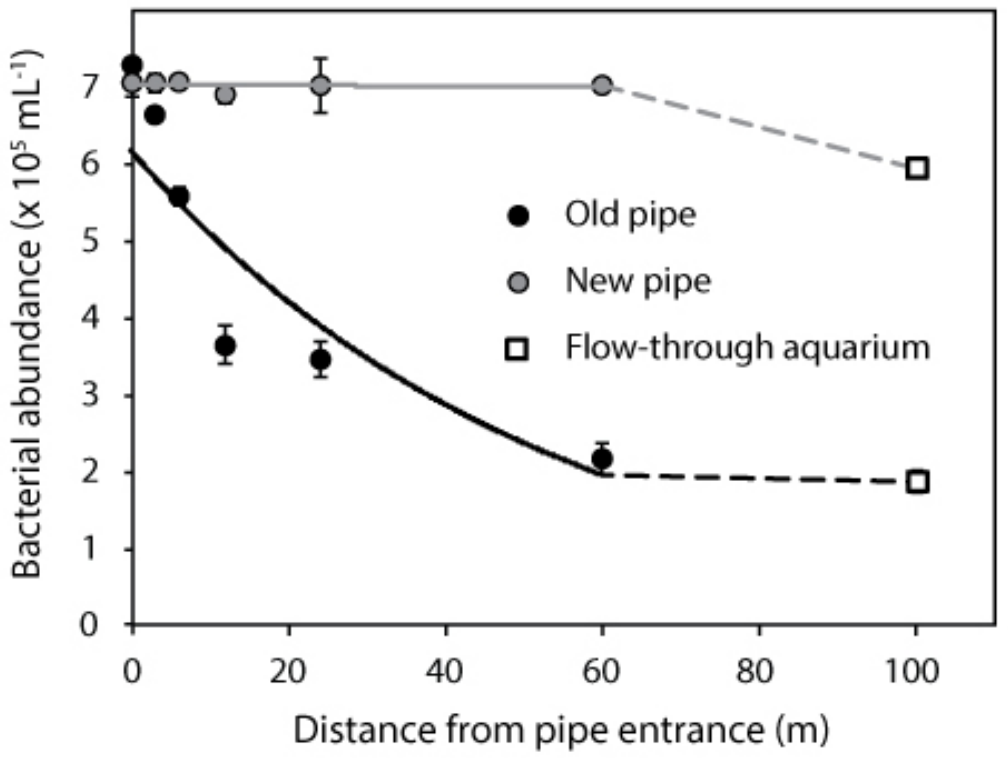

Figure 2. Bacterial abundance along the old (black circles) and new (grey circles) inlet models for bacterial abundance within the first $60 \mathrm{~m}$ of inlet pipe (i.e. the section that was replaced). The dotted lines represent differences in bacterial abundance between the flow-

465 through aquarium, which was $100 \mathrm{~m}$ from the inlet pipe entrance, and the replaced section of the 466 inlet pipe. 

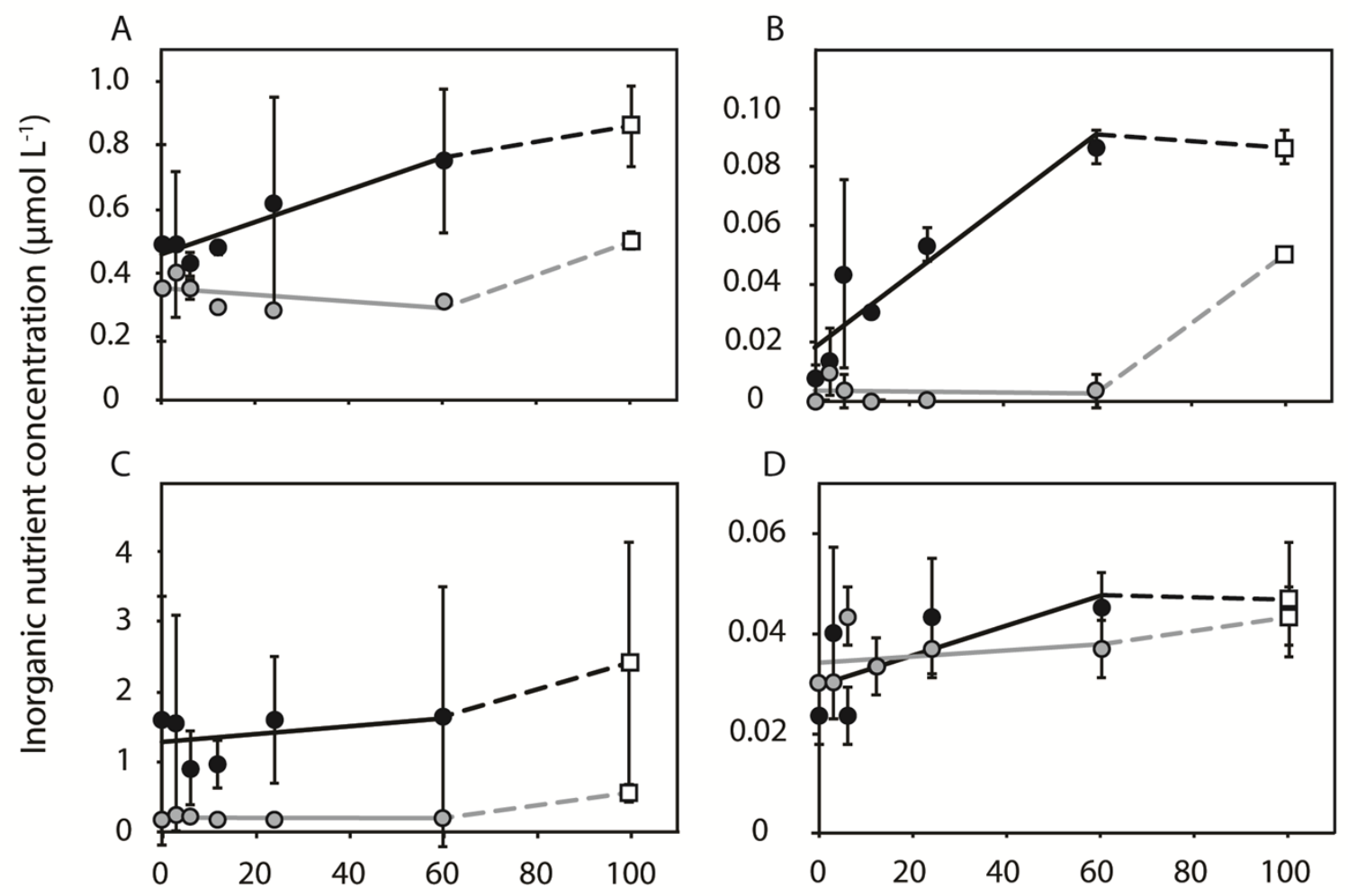

- Old pipe

Distance from pipe entrance $(\mathrm{m})$

○ New pipe

Flow-through aquarium

Figure 3. (A) Nitrate $\left[\mathrm{NO}_{3}^{-}\right]$, (B) nitrite $\left[\mathrm{NO}_{2}^{-}\right],(\mathrm{C})$ ammonium $\left[\mathrm{NH}_{4}^{+}\right]$, and (D) phosphate

circles), and in the aquarium (open squares). Solid lines indicate linear models for inorganic

472 was $100 \mathrm{~m}$ from the entrance of the inlet pipe. The dotted lines represent differences in inorganic

473 nutrient concentrations between the flow-through aquarium and the replaced section of the inlet 474 pipe. 


\section{Tables}

476 Table 1. Water quality parameters (bacterial abundance $[\mathrm{BA}]$, nitrate $\left[\mathrm{NO}_{3}^{-}\right]$, nitrite $\left[\mathrm{NO}_{2}^{-}\right]$, 477 ammonium $\left[\mathrm{NH}_{4}{ }^{+}\right]$, and phosphate $\left.\left[\mathrm{PO}_{4}{ }^{3-}\right]\right)$ and $\mathrm{H}$. caerulea choanocyte proliferation rates in a 478 flow-through aquarium fed with water from the old (+ biofouling) and new inlet pipe (479 biofouling). Means $\pm \mathrm{SD}$ are shown $(n=3)$. Percentage increases or decreases in the 480 aforementioned parameters between the old and the new pipe are given. NA: not applicable, i.e. 481 no significant difference.

\section{Water quality parameters}

\begin{tabular}{lccccc}
\hline & $\begin{array}{c}\mathrm{BA} \\
\left(\mathrm{x} 10^{5} \mathrm{~mL}^{-1}\right)\end{array}$ & $\begin{array}{c}\mathrm{NO}_{3}^{-} \\
\left(\mu \mathrm{mol} \mathrm{L}^{-1}\right)\end{array}$ & $\begin{array}{c}\mathrm{NO}_{2}^{-} \\
\left(\mu \mathrm{mol} \mathrm{L}^{-1}\right)\end{array}$ & $\begin{array}{c}\mathrm{NH}_{4}^{+} \\
\left(\mu \mathrm{mol} \mathrm{L}^{-1}\right)\end{array}$ & $\begin{array}{c}\mathrm{PO}_{4}^{3-} \\
\left(\mu \mathrm{mol} \mathrm{L}^{-1}\right)\end{array}$ \\
\hline $\begin{array}{l}\text { Aquarium water } \\
+ \text { biofouling }\end{array}$ & $1.9 \pm 0.1$ & $0.86 \pm 0.04$ & $0.09 \pm 0.01$ & $2.42 \pm 1.73$ & $0.04 \pm 0.01$ \\
$\begin{array}{l}\text { Aquarium water } \\
\text { - biofouling } \\
\text { \% increase or decrease } \\
\text { from old pipe to new } \\
\text { pipe }\end{array}$ & 217 & -42 & -42 & -77 & $\mathrm{NA}$ \\
\hline
\end{tabular}

\section{H. caerulea choanocyte proliferation}

\begin{tabular}{lc}
\hline & \% BrdU-positive choanocytes \\
\hline $\begin{array}{l}\text { Aquarium water } \\
+ \text { biofouling }\end{array}$ & $15.1 \pm 1.9$ \\
$\begin{array}{l}\text { Aquarium water } \\
\text { - biofouling }\end{array}$ & $20.2 \pm 3.8$ \\
$\begin{array}{l}\text { \% increase or decrease } \\
\text { from old pipe to new } \\
\text { pipe }\end{array}$ & 34 \\
\hline
\end{tabular}

